\title{
Co můžeme očekávat od Basel III?
}

\section{Vážení čtenáři,}

třetí číslo Českého finančního a účetního časopisu si dovolím věnovat zamyšlení nad tím, co lze očekávat od Basel III. Průběh a dopady globální finanční krize byly natolik silné, že nemohly nezůstat bez reakce politiků i regulátorů. A tak regulátoři přicházejí s novými návrhy na zpřísnění regulatorních pravidel, která by již neměla dopustit opakování finanční krize podobných rozměrů. A politické reprezentace včetně těch, které se vždy stavěly $\mathrm{k}$ př́lišné regulaci odmítavě, nacházejí pro nové návrhy mnohem větší pochopení, než tomu bylo kdy v minulosti. Změny se přirozeně musely dotknout i kapitálové př̌iměřenosti, která představuje jeden ze základních pilírư bankovní regulace.

Jaké změny bankám zavedení Basel III přinese a co od nich lze očekávat? Stručně řečeno by mělo dojít především k navýšení minimálního kapitálu, posílit by se měla i jeho kvalita, což by se vše mělo pozitivně projevit ve větší stabilitě finančního systému.

Navýšení minimálního kapitálu (přesněji řečeno kapitálové přiměřenosti) bude po bankách požadováno dvěma základními cestami. První spočívá v zavedení kapitálového polštáře (conservation buffer) ve výši 2,5 \% nad regulatorní minimum, který by měl sloužit k pokrytí zvýšených ztrát bank v době, kdy se ekonomice nebude dařit a banky v důsledku toho budou vykazovat větší ztráty. Banky nebudou mít automaticky povinnost takový kapitál vytvořit, nicméně pokud by tak neučinily, podléhaly by určitým restrikcím na výplatu dividend akcionářum a bonusů manažerům. Tomu se banky budou chtít spíše vyhnout, proto lze očekávat, že budou toto kapitálové navýšení dobrovolně naplňovat.

Druhou formou je proticyklický polštář (countercyclical buffer), který by měl omezit kritizovanou slabinu současného Basel II, a sice jeho spíše procyklický charakter. Uplatnění tohoto polštáře bude $\mathrm{v}$ pravomoci národního regulátora, který bude mít možnost navýšit kapitálový poměr až o 2,5 procentního bodu, pokud v ekonomice poroste objem úvěrů rychleji než HDP. K navýšení kapitálu by tak mělo docházet u bank s předstihem v době, kdy ekonomika poroste, a naopak v období recese bude takto vytvořený kapitál využit na krytí vzniklých ztrát.

Navýšení kapitálu je většinou považováno za potřebné, protože dosavadní kapitálový polštář se ukázal jako naprosto nedostatečný. Na druhé straně si je třeba uvědomit, že i plánované navýšení kapitálu nemůže zajistit přežití všech bank během možné krize, protože pokles hodnoty aktiv může být samozřejmě vyšší, než kolik budou banky schopny pokrýt i z navýšeného kapitálu. Svoji významnou roli zde bude hrát i oceňování aktiv, protože na novou požadovanou úroveň kapitálového poměru se banky budou moci dostat nejen přes navýšení kapitálu, ale i prostřednictvím snížení rizikově vážených aktiv. A právě při jejich stanovení hraje oceňování se zohledněním spojených rizik zásadní význam.

Vedle kvantitativního navýšení kapitálu klade Basel III větší důraz i na jeho kvalitativní složení. To se projevuje v tom, že se zvyšuje ukazatel kapitálové přiměřenosti založený na základním kapitálu, resp. na kapitálu Tier 1. Banky tak budou muset potřebný nový kapitál získat i formou rozšîrení základního kapitálu. $\mathrm{Z}$ teoretického pohledu by to mělo přispět ke zvýšení odpovědnosti akcionářu za fungování bank. Praktický dopad je však v tomto směru sporný, protože finanční krize nám ukázala, že odpovědnost akcionářù v prrípadě řady 
zejména velkých bank př́liš nefungovala. Banky se pod vidinou vysokého zhodnocení často pouštěly do relativně velmi rizikových operací, které ohrozily samotnou existenci bank (a v některých případech vedly až $\mathrm{k}$ jejich pádu) a akcionáři jim v tom nezabránili. Celý problém však není až tak jednoduchý, jak se nám dnes zdá. Je třeba si uvědomit, že to co je všem dnes jasné, se před vypuknutím krize jevilo podstatně jinak. Sofistikované metody měření rizik, objektivní ratingové hodnocení, propracovaná regulace - to jsou jen některé charakteristiky, které nikdo př́liš před krizí nezpochybňoval a které svým způsobem oprávněně vyvolávaly spíše pozitivní očekávání. Těžko proto lze dnes vinit akcionáře, že vysoká rizika včas neidentifikovali. A nejen to. Na základě této zkušenosti není proto možné ani předpokládat, že vyšší dopad na akcionáře $\mathrm{v}$ důsledku vyššího podílu základního kapitálu v bankách, přinese z jejich strany významný tlak na omezení rizik podstupovaných těmito bankami. Možná by to fungovalo u dnes známých instrumentů a s nimi spojených rizik, vývoj se však nezastaví a nové problémy lze očekávat spíše s novými instrumenty.

Tak tedy co lze od nových pravidel očekávat? Určitě přinesou díky vyššímu kapitálu vyšší schopnost bank vyrovnat se s možnými ztrátami. Na druhé straně nás již historie dostatečně poučila v tom, že žádná regulace nezabezpečí stoprocentně stabilní systém a o finančním systému to platí dvojnásob. Proto nakonec bude rozhodující chování všech subjektů vyplývající z jejích vnitřních motivací. A tak jako jejich chování nebude nikdy u všech dostatečně obežretné, ani regulace nemůže takovou obezřetnost plně vynutit. Může ji pouze určitým způsobem usměrňovat.

Basel III stabilitě finančního systému spíše prospěje, jaké však budou jeho skutečné dopady, do jaké míry se naplní cíle, které do něj jeho tvưrci vkládají, či naopak jak moc banky budou hledat, nacházet a uplatňovat cestičky, kterými se budou snažit novým pravidlům vyhýbat, to bude možné hodnotit až v horizontu 10-15 let. Harmonogram zavádění Basel III je totiž rozvržen až do roku 2019.

doc. Ing. Petr Dvořák, Ph.D.

děkan Fakulty financí a účetnictví

Vysoké školy ekonomické v Praze 